Dinamika Sosial Budaya, Vol 22, No. 2, Desember 2020, pp 234-247

p-ISSN: 1410-9859\& e-ISSN: 2580-8524

http://journals.usm.ac.id/index.php/jdsb

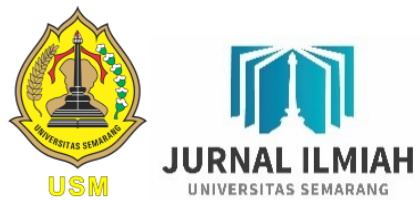

\title{
Pengaruh Variabel Sosial Teknologi dan Informasi Terhadap Ketimpangan Gender
}

\author{
Oeliestina \\ Badan Pusat Statistik Provinsi Jambi, Jambi, Indonesia \\ DOI: $\underline{\text { http://dx.doi.org/10.26623/ jdsb.v21i2.1698 }}$
}

\begin{abstract}
Abstrak
Era milenial identik dengan perkembangan teknologi yang pesat. Era ini juga menuntut perempuan untuk lebih mengembangkan diri, baik kualitas maupun kemampuan dirinya menguasai teknologi informasi. Kemampuan ini diperlukan agar perempuan bisa sejajar dengan laki-laki. Kesetaraan perempuan dengan laki-laki bisa dilihat dari pencapaian Indeks Ketimpangan Gender (IKG) yang dihitung oleh Badan Pusat Statistik. Semakin rendah angka Indeks Ketimpangan Gender (IKG) semakin bagus kemampuan perempuan untuk sederajat dengan laki-laki. Penelitian ini akan mengamati variabel sosial teknologi informasi yang dianggap berkorelasi dengan Indeks Ketimpangan Gender (IKG). Variabel tersebut antara lain Indeks Pembangunan Manusia (IPM), Indeks Pembangunan Gender (IPG), persentase perempuan yang membaca media cetak dan elektronik, persentase perempuan yang memiliki Hand Phone, persentase perempuan yang menggunakan komputer dan persentase perempuan yang mengakses internet. Penelitian menggunakan korelasi pearson dengan analisis deskriptif. Hasil penelitian menunjukkan terdapat korelasi yang kuat, signifikan dan negatif antara variabel sosial teknologi informasi dengan Indeks Ketimpangan Gender (IKG). Hal ini menjadi pembuktian, bahwa variabel sosial teknologi berpengaruh terhadap kesetaraan gender.
\end{abstract}

\begin{abstract}
Millennial era is synonymous with rapid technological development. This era also requires women to further develop themselves, both quality and ability to master information technology. This ability is needed so that women can be equal with men. Equality between women and men can be seen from the achievement of the Gender Inequality Index (IKG) calculated by the Central Statistics Agency. The lower the Gender Inequality Index (IKG) the better the ability of women to be equal to men. This research will observe social information technology variables that are considered to correlate with the Gender Inequality Index (IKG). These variables include the Human Development Index (HDI), the Gender Development Index (IPG), the percentage of women who read print and electronic media, the percentage of women who have hand phones, the percentage of women who use computers and the percentage of women who access the internet. The study uses Pearson correlation with descriptive analysis. The results showed that there was a strong, significant and negative correlation between the social variables of information technology and the Gender Inequality Index (IKG). This proves that social variables of technology influences gender equality.
\end{abstract}

Keywords: Gender Inequality Index; Internet; Millenial Era; Hand Phone; Technology ; 
Dinamika Sosial Budaya, Vol 22, No. 2, Desember 2020, pp 234-247

p-ISSN: 1410-9859\& e-ISSN: $2580-8524$

http://journals.usm.ac.id/index.php/jdsb

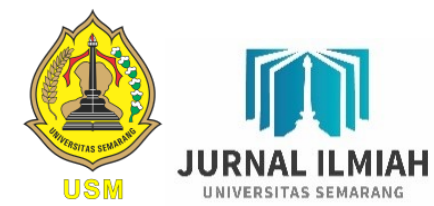

\section{PENDAHULUAN}

Era milenial ditandai oleh penemuan teknologi bernama internet. Era yang menuntut kecepatan dan kemudahan di segala bidang dengan berlandaskan digitech (digital teknologi). Beda dengan perilaku perempuan yang identik dengan kelembutan dan kelambatan. Milenial harusnya memiliki ruang bagi perempuan dimanapun berada. Sejajar dengan kaum pria, mempunyai hak dan kewajiban sama.

Berperan sebagai warga negara, istri bagi suaminya, ibu untuk anaknya, tokoh panutan masyarakatnya dan pemimpin yang bijak dalam mengambil keputusan untuk kepentingan orang banyak. Perempuan harus sejajar dengan pria di era milenial dengan bermodalkan kualitas diri. Di iringi kemampuan menguasai teknologi tanpa harus meninggalkan kewajiban-kewajiban yang sudah tertulis untuknya baik secara kodrati maupun manusiawi. Nilai sejajar ini dalam lingkup yang luas disebut kesetaraan gender.

Permasalahan gender akan senantiasa menarik untuk dibahas, karena konflik kepentingan yang melibatkan hak-hak kaum feminis selalu menimbulkan pro dan kontra. Bahkan, ranah pembicaraan masalahnya bisa sampai internasional. Seperti yang dipublikasikan World Economic Forum dalam global gender gap report 2020. Sistem yang dibangun dalam buku tahunan tersebut mengurutkan 153 negara di dunia berdasarkan Global Gender Gap Indeks (GGGI). Tahun 2020 Indonesia menempati posisi ke-85, dua peringkat di atas Vietnam dan 4 level di bawah Rusia. Angka Global Gender Gap Indeks Indonesia mencapai skor 0,700 selisih 0,177 dengan negara Iceland yang menduduki rangking satu (World Economic Forum, 2019).

Indonesia juga memiliki angka yang fungsinya mirip dengan Global Gender Gap Indeks yaitu Indeks Pemberdayaan Gender (IDG). Walaupun konsep/pendekatan agak berbeda dengan Global Gender Gap Indeks (GGGI). Namun inti pembicaraan sama mengenai kesetaraan. Indeks Pemberdayaan Gender (IDG) berbasis pada 4 indikator dengan 3 dimensi sama halnya dengan United Nations Development Program (UNDP) dalam menghitung Gender Empowerment Measure (GEM) dan new Gender Development Index (nGDI). Posisi Indonesia lebih rendah dalam penghitungan gender UNDP/nGDI yaitu pada rangking 111 pada Publikasi Human Development Report (HDR) tahun 2019. Dua level di atas Afrika Selatan dan lima tingkat di bawah negara Pilipina. Kendati demikian, UNDP masih menempatkan Indonesia pada High Human Development karena Human Development Index (HDI) Indonesia masih di atas 70 (United Nations Development Programme, 2019).

Indeks Pemberdayaan Gender (IDG) merupakan alat ukur untuk menunjukkan apakah perempuan mampu memainkan peranan aktif dan memiliki power dalam kehidupan sosial, ekonomi dan politik (Badan Pusat Statistik, 2015). Kata pemberdayaan mengacu kepada proses dan bukan hasil akhirnya. Secara kronologi sistematis mencerminkan tahapan upaya kaum hawa yang kurang dan belum berdaya menuju kejayaannya. Konsep Indeks Pemberdayaan Gender (IDG) lebih ditekankan pada opportunity daripada outcome. Penilaiannya mengacu pada proses pembangunan kapasitas yang mengarah pada partisipasi, pengambilan keputusan, kontrol dan tindakan perubahan ke 
Dinamika Sosial Budaya, Vol 22, No. 2, Desember 2020, pp 234-247

p-ISSN: 1410-9859\& e-ISSN: 2580-8524

http://journals.usm.ac.id/index.php/jdsb

arah yang lebih baik dan meluas. Walaupun masih mempunyai beberapa kelemahan. Indeks Pemberdayaan Gender (IDG) saat ini diakui sebagai alat ukur sah indikator gender yang menyiratkan kemampuan perempuan dalam tatanan kemasyarakatan untuk bersaing dengan partnernya yaitu kaum adam.

Selain Indeks Pemberdayaan Gender (IDG), indikator lain yang biasanya dipakai adalah Indeks Pembangunan Gender (IPG) dengan komponen sama seperti Indeks Pembangunan Manusia (IPM). Karena pada intinya Indeks Pembangunan Gender (IPG) mengukur ketidaksetaraan antara laki-laki dan perempuan dalam hal kualitas hidup yang berbasis pada kapabilitas dasar. Indeks Pembangunan Gender (IPG) adalah indikator turunan Indeks Pembangunan Manusia (IPM) yang dipilah menurut gender. Teknis penghitungan Indeks Pembangunan Gender (IPG) merupakan perbandingan Indeks Pembangunan Manusia (IPM) perempuan dan Indeks Pembangunan Manusia (IPM) laki-laki.

Kedua indeks diatas memiliki kelemahan secara teknis dan konseptual. Indeks Pemberdayaan Gender (IDG) menggunakan bobot yang sama (equal weighting) untuk setiap komponen penyusunnya padahal setiap komponen indeks harusnya memiliki varians yang berbeda. Indeks Pemberdayaan Gender (IDG) mencerminkan urban elite bias dengan menggunakan indikator yang relevan bagi negara maju. Kegagalan mengukur kekuatan perempuan dalam mengambil keputusan di tingkat domestik rumah tangganya menjadi sebuah kelemahan juga. Sedangkan Indeks Pembangunan Gender (IPG) dalam hal mengukur angka harapan hidup sangat lemah.

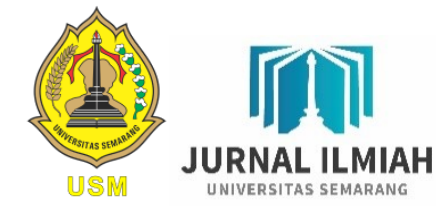

Secara genetis ketahanan hidup lakilaki dan perempuan berbeda sehingga tidak rasional sebenarnya kalau disandingkan. Kelemahan lain, pendapatan dalam bentuk nominal teramat rentan menarik Indeks Pembangunan Manusia (IPM) perempuan menjadi jauh lebih rendah dan tidak semua wilayah memiliki data pendapatan, faktor imputasi menjadi nilai minus bagi penghitungan indikator ini.

Untuk menutupi kekurangan Indeks Pemberdayaan Gender (IDG) dan Indeks Pembangunan Gender (IPG) maka dilakukan penghitungan Indeks Ketimpangan Gender (IKG) yang dalam dunia internasional dikenal dengan Gender Inequality Indeks (GII). Dimana perbaikan metodologi diterapkan dalam tiga dimensi yatu kesehatan reproduksi, pemberdayaan dan partispasi dalam pasar tenaga kerja. Formula penghitungan Indeks Ketimpangan Gender (IKG) sudah mempertimbangkan berbagai komponen seperti pembobotan dan pengagregasian.

Indeks Ketimpangan Gender (IKG) mampu mengukur kesetaraan perempuan dengan laki-laki. Indeks Ketimpangan Gender (IKG) mengukur kesenjangan pada tiga aspek yaitu kesehatan reproduksi, pemberdayaan meliputi tenaga profesional dan pendidikan serta status ekonomi. Semakin tinggi nilai Indeks Ketimpangan Gender (IKG) pada suatu daerah menunjukkan ketimpangan capaian antara laki-laki dan perempuan semakin besar, yang akan menyebabkan kerugian pada pembangunan manusia khususnya kaum perempuan. 
Dinamika Sosial Budaya, Vol 22, No. 2, Desember 2020, pp 234-247 p-ISSN: 1410-9859\& e-ISSN: 2580-8524

http://journals.usm.ac.id/index.php/jdsb

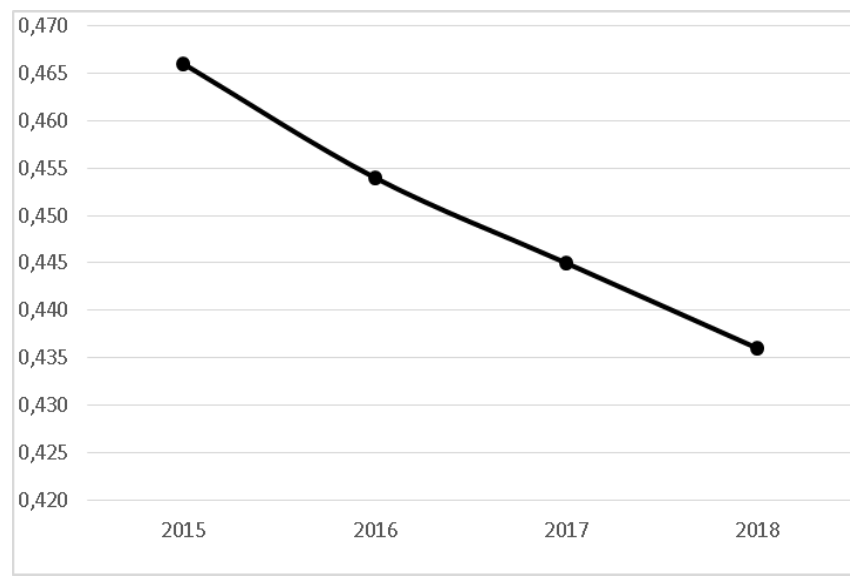

Gambar 1. Pencapaian Indeks Ketimpangan Gender (IKG) di Indonesia, 2015-2018

Indeks Ketimpangan Gender (IKG) Indonesia dari tahun 2015 hingga tahun 2018 terus mengalami penurunan. Pencapaian Indeks Ketimpangan Gender (IKG) tahun 2015 hanya 0,466 , semakin menurun hingga 0,436 pada tahun 2018 (gambar 1). Artinya tingkat ketimpangan gender semakin baik. Pencapaian pembangunan semakin menguntungkan perempuan, akses ke arah hasil-hasil pembangunan seperti sarana kesehatan dan pendidikan semakin mudah dilakukan perempuan. Demikian juga dengan pilihan yang disediakan akan semakin beragam dan hal tersebut bisa mengembangkan potensi perempuan.

Potensi dan jumlah perempuan yang besar diharapkan dapat membantu laki-laki memajukan negeri. Rasio jenis kelamin penduduk Indonesia mencapai 101,09, artinya jumlah perempuan hampir sama dengan jumlah laki-laki. Demikian juga dengan persentase penduduk perempuan yang secara nasional mencapai 49,76. Perannya yang strategis dalam kehidupan berkeluarga, berbangsa dan bermasyarakat baik sebagai ibu rumah tangga biasa, pendidik, pekerja

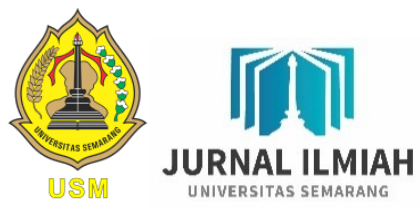

maupun pengambil keputusan penting harus sejalan dengan kualitas yang dimiliki perempuan. Kualitas perempuan akan baik jika diiringi dengan pendidikan, keterampilan, kesehatan, penguasaan teknologi, pendapatan dan posisi dalam masyarakat.

Di era milenial faktor penguasaan teknologi akan sangat berpengaruh terhadap pola, gaya hidup bahkan pendapatan dan kedudukan seseorang di tengah masyarakat. Sayangnya persentase perempuan Indonesia yang menggunakan internet masih rendah, tahun 2018 hanya mencapai 37,49 persen. Padahal, saat sekarang manusia sangat bergantung dengan kehidupan daring, jual beli online, bersosialita, belajar, dan mengakses beragam informasi dari dunia maya.

Begitu besarnya ketergantungan generasi milenial dengan internet, akan menciptakan pola perekonomian baru yang harus dilewati juga oleh kaum perempuan. Proses cepat dengan hasil instan menjadi ciri khas pencipta peradaban "zaman now" yang masyarakatnya bersaing memperebutkan kebutuhan ekonomi dan sosial serta berpacu dengan kemajuan teknologi. Siapa yang menguasai teknologi dan mudah beradaptasi dengan kemampuan digitalnya akan memenangkan pertarungan. Benarkah variabel sosial teknologi informasi memiliki pengaruh terhadap kesetaraan gender?

Penelitian mengenai gender sudah banyak dilakukan baik di dalam negeri maupun luar negeri. Buku pembangunan manusia berbasis gender yang dibuat oleh Kementrian Pemberdayaan Perempuan dan Perlindungan Anak dengan Badan Pusat Statistik banyak mengangkat tentang gender dan seluk beluknya di Indonesia (Badan Pusat 
Dinamika Sosial Budaya, Vol 22, No. 2, Desember 2020, pp 234-247

p-ISSN: 1410-9859\& e-ISSN: 2580-8524

http://journals.usm.ac.id/index.php/jdsb

Statistik, 2015). Penelitian yang dilakukan oleh Soetji Lestari dkk memaparkan tentang potret pembangunan manusia berbasis gender di kabupaten Banyumas (Lestari dkk, 2017). Indeks Pemberdayaan Gender (IDG) juga dapat digunakan untuk memetakan suatu daerah apakah pembangunan manusia pada wilayah tertentu sudah berbasis gender apa belum seperti penelitian tentang gender analisis dan pemetaan indeks pemberdayaan di kabupaten Kutai Kartanegara (Jais, n.d., 2016)

Analisis ketimpangan gender di Provinsi Sumatera Barat dalam jurnal kependudukan Indonesia dengan metode biplot menunjukkan hasil beberapa kabupaten/kota memiliki tingkat ketimpangan gender yang tinggi (Rita Diana, 2018). Sementara itu beberapa peneliti mengaitkan dampak ketimpangan gender terhadap pertumbuhan ekonomi (Ahang, 2014). Peneliti yang lain mengangkat isu gender yang sangat berpengaruh dalam dinamika pembangunan manusia (Alfana et al., 2015) dan pembangunan gender dapat dijadikan indikator mengukur keberhasilan pembangunan perekonomian daerah Sumatera Utara (Elvina, 2013).

Demikian juga dengan studi mengenai keterkaitan perempuan dengan teknologi, seperti penelitian Evawani Elysa Lubis mengungkapkan internet telah menjadi faktor yang penting dalam kehidupan sehari hari terutama perempuan yang sangat aktif dalam media sosial (Lubis, 2014). Penggunaan Teknologi dan Informasi mampu membantu perempuan dalam bidang ekonomi melalui perdagangan online ((Najih, 2017). Terdapatpenelitian yang telah membuktikan bahwa internet mampu mengaburkan batas marginal dan feminity bagi perempuan untuk

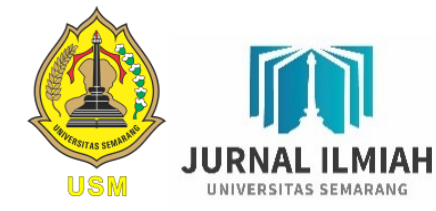

berkiprah dalam bisnis start up (R. K. Ayu, 2017)

Masalah gender akan selalu menarik untuk dibahas, banyak kepentingan dan manfaat yang diambil dari setiap penelitian tentang kesetaraan. Penelitian ini bertujuan untuk melihat apakah teknologi informasi mempengaruhi pencapaian pembangunan berbasis kesetaraan gender. Hal tersebut dapat diamati dengan melihat angka Indeks Ketimpangan Gender (IKG) pada provinsiprovinsi di Indonesia. Apakah perempuan Indonesia yang menguasai teknologi informasi mampu membuat dirinya sejajar dengan laki-laki. Kajian ini diharapkan mampu melihat hubungan beberapa variabel sosial yang berkaitan dengan teknologi dan informasi terhadap Indeks Ketimpangan Gender (IKG). Sehingga bisa dibuat analisa yang dapat dipergunakan untuk mengambil kebijakan yang tepat berkaitan dengan kesetaraan gender.

\section{METODE}

Penelitian ini menggunakan analisis korelasi untuk melihat hubungan antara variabel sosial terkait penguasaan teknologi dan informasi dengan Indeks Ketimpangan Gender (IKG). Variabel yang dipakai antara lain Indeks Pembangunan Manusia (IPM), Indeks Pembangunan Gender (IPG), persentase wanita yang membaca media cetak dan elektronik, persentase perempuan yang memiliki Hand Phone, persentase perempuan yang menggunakan komputer dan persentase pengguna internet perempuan.

Data yang dianalisa merupakan angka 34 Provinsi. Dari Aceh hingga Papua barat akan disajikan korelasi Indeks Ketimpangan Gender (IKG) dengan variabel sosial 
Dinamika Sosial Budaya, Vol 22, No. 2, Desember 2020, pp 234-247 p-ISSN: 1410-9859\& e-ISSN: 2580-8524 http://journals.usm.ac.id/index.php/jdsb

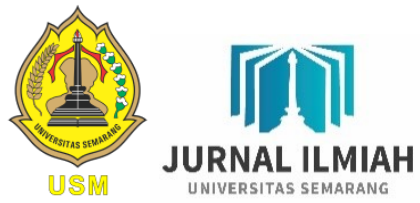

teknologi informasi. Penelitian ini menggunakan data sekunder milik Badan Pusat Statistik yang dengan mudah diperoleh dari laman websitenya.

(IKG) dari buku $\begin{array}{ccc}\text { Data } & \text { Indeks } & \text { Ketimpangan Gender } \\ \text { datungan } & \text { Indeks }\end{array}$ Ketimpangan Gender 2018 (Kajian Lanjutan 2). Data IPG dan IPM berasal dari publikasi Indeks Pembangunan Manusia Badan Pusat Statistik 2018. Data sosial yang berkaitan dengan penggunaan teknologi dan informasi didapatkan dari publikasi Statistik Kesejahteraan Rakyat 2018. Angka dalam publikasi ini merupakan hasil olah SUSENAS (Survei Sosial Ekonomi Nasional) 2018.

Semua faktor sosial dan teknologi informasi yang dianalisis akan dihitung terlebih dahulu normalitas dan linieritasnya, karena analisis korelasi bivariate mensyaratkan asumsi dasar sebagai berikut :

1. Data penelitian untuk masing-masing variabel setidaknya berskala rasio atau interval, data yang berbentuk angka sesungguhnya berupa data numerik/kuantitatif.

2. Data untuk masing-masing variabel yang dihubungkan berdistribusi normal

3. Terdapat hubungan yang linier antara variabel penelitian.

4. Analisis korelasi bivariate pearson dilakukan untuk melihat seberapa kuatvariabel yang satu mempengaruhi variabel lain dan mengamati arah pengaruhnya, positif atau negatif. Apabila arah positif maka kedua variabel bergerak ke arah yang seirama, dan sebaliknya apabila negatif maka arahnya berlawanan. Selanjutnya analisis deskriptif dengan melihat pengaruh variabel secara luas. Berikut merupakan rumus korelasi pearson:

$$
r=\frac{\sum x y-\frac{\left(\sum x\right)\left(\sum y\right)}{n}}{\sqrt{\left(\sum x^{2}-\frac{\left(\sum x\right)^{2}}{n}\right)\left(\sum y^{2}-\frac{\left(\sum y\right)^{2}}{n}\right)}}
$$

Keterangan :

$\mathrm{r}=$ korelasi pearson antara variabel $\mathrm{x}$ dan $\mathrm{y}$, bernilai $-1 \leq \mathrm{r} \leq 1$, tanda $(+)$ dan (-) menandakan arah hubungan

$\mathrm{n}=$ jumlah sampel $\mathrm{x}=$ nilai variabel $\mathrm{X}, \mathrm{y}=$ nilai variabel $Y$

\section{HASIL DAN PEMBAHASAN}

Pengukuran Indeks Ketimpangan Gender (IKG) tahun 2018 menghasilkan angka 0,436 mengalami penurunan dibanding tahun sebelumnya yang mencapai 0,445 . Artinya ketimpangan semakin mengecil dan kesetaraan mendekati angka 0 (nol) berarti semakin bagus. Kondisi Indeks Ketimpangan Gender (IKG) tiap provinsi berbeda-beda, provinsi dengan pencapaian kesetaraan yang bagus antara lain Bali dan DI Yogyakarta (dibawah 0,200), disusul DKI Jakarta, Jawa Tengah, dan Jawa Timur (di bawah 0,400). Sementara Provinsi di pulau sumatera diwakili Sumatera barat $(0,362)$ dan di Indonesia kawasan timur ada provinsi Gorontalo dengan angka IKG 0,390 (Badan Pusat Statistik, 2019) . 
Dinamika Sosial Budaya, Vol 22, No. 2, Desember 2020, pp 234-247 p-ISSN: 1410-9859\& e-ISSN: 2580-8524 http://journals.usm.ac.id/index.php/jdsb

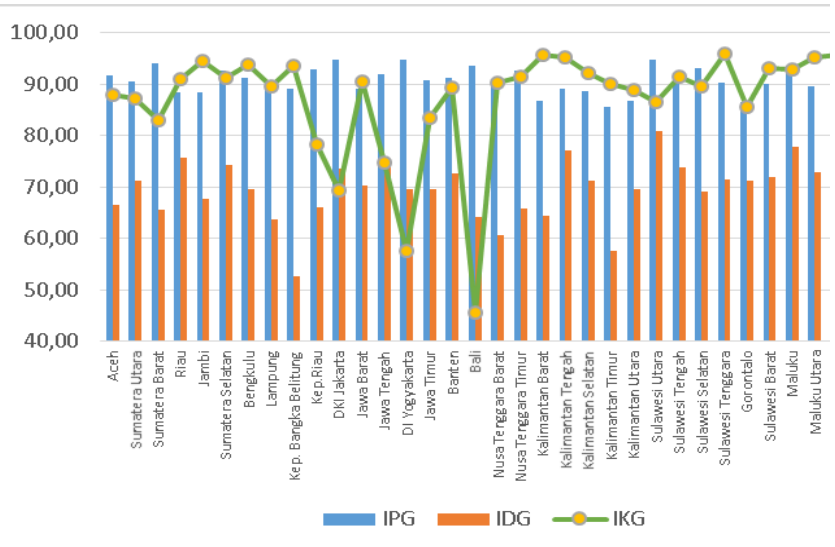

Gambar 2. Pencapaian Indeks Pembangunan Gender(IPG), Indeks Pemberdayaan Gender (IDG) dan Indeks Ketimpangan Gender (IKG) Menurut Provinsi di Indonesia, 2018

Gambar 2 menjelaskan pencapaian angka Indeks Pembangunan Gender (IPG), Indeks Pemberdayaan Gender (IDG) dan Indeks Ketimpangan Gender (IKG) di Indonesia. Provinsi Sulawesi Utara mencapai Indeks Pembangunan Gender (IPG) dan Indeks Pemberdayaan Gender (IDG) tertinggi. Pencapaian Indeks Pembangunan Gender (IPG) terendah di Papua dan Indeks Pemberdayaan Gender (IDG) paling kecil seIndonesia di Papua Barat, sedangkan provinsi lain keadaannya bervariasi. Deretan provinsi di pulau sumatera dengan Indeks Pembangunan Gender (IPG) tertinggi yaitu Sumatera Barat. Sementara itu Indeks Pemberdayaan Gender (IDG) rangking satu yaitu provinsi Riau tetapi dengan Indeks Pembangunan Gender (IPG) terendah $(88,44)$. Sedangkan Indeks Pemberdayaan Gender (IDG) terendah provinsi Bangka belitung yang mencatatkan angka 52,57.

Pencapaian Indeks Pembangunan Gender (IPG) dan Indeks Pemberdayaan Gender (IDG) di pulau Jawa cukup bagus.
Kisaran IPG pada angka 90 untuk 6 provinsi dan Indeks Pemberdayaan Gender (IDG) pada kisaran 70. Beberapa provinsi di pulau Kalimantan memiliki Indeks Pembangunan Gender (IPG) di bawah 90 dan Indeks Pemberdayaan Gender (IDG) dengan kisaran 57-77.

Provinsi yang ada di pulau Sulawesi memiliki Indeks Pembangunan Gender (IPG) yang bagus, terbukti Sulawesi Utara menduduki peringkat pertama nasional walaupun provinsi Gorontalo hanya mencapai angka 86,63. Indeks Pemberdayaan Gender (IDG) juga berada pada kisaran 70, hanya Sulawesi Selatan yang mencatatkan angka terendah yaitu 69,14. Indeks Pembangunan Gender (IPG) dan Indeks Pemberdayaan Gender (IDG) boleh tidak seiring sejalan karena komponen pendukung untuk masingmasing indeks berbeda.

Sementara itu, angka Indeks Ketimpangan Gender (IKG) dapat diamati dengan melihat trend penurunannya. Provinsi dengan Indeks Ketimpangan Gender terbaik yaitu provinsi Bali, disusul DI Yogyakarta, DKI Jakarta, Jawa Tengah dan Kepulauan Riau. Ketimpangan paling dalam, dimana angka Indeks Ketimpangan Gendernya (IKG) lebih dari 0,500 adalah Provinsi Jambi, Kalimantan Tengah, Maluku Utara, Kalimantan Barat, Papua Barat dan Sulawesi Tenggara.

\section{Indeks Pembangunan Manusia}

Indeks Pembangunan Manusia (IPM) Indonesia tahun 2018 mencapai 71,39. Ada 8 Provinsi yang angka Indeks Pembangunan Manusia (IPM) berada diatas nasional yaitu : DKI Jakarta, DI Yogyakarta, Kalimantan timur, Kepulauan Riau, Bali, Riau, Sulawesi Tenggara dan Banten. Besarnya angka Indeks 
Dinamika Sosial Budaya, Vol 22, No. 2, Desember 2020, pp 234-247 p-ISSN: 1410-9859\& e-ISSN: 2580-8524

http://journals.usm.ac.id/index.php/jdsb

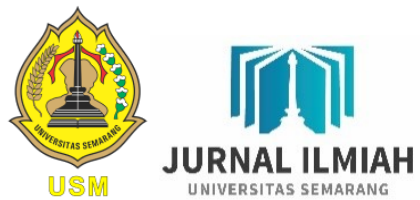

Pembangunan Manusia (IPM) merupakan indikator keberhasilan pembangunan suatu daerah dalam upaya meningkatkan kualitas hidup masyarakatnya (https://ipm.bps.go.id/).

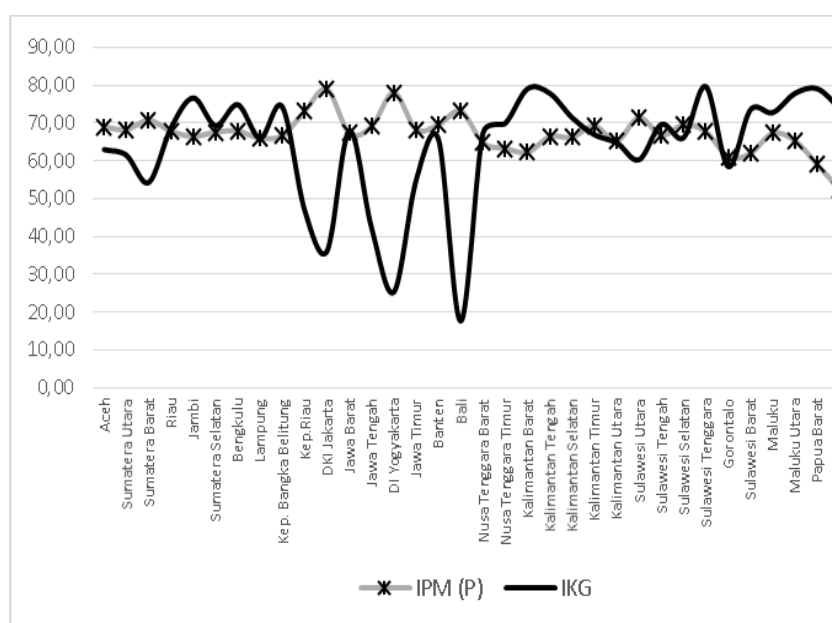

Gambar 3. Indeks Ketimpangan Gender (IKG) dan Indeks Pembangunan Manusia Perempuan (IPM_P) menurut Provinsi di Indonesia, 2018

Apabila dibandingkan antara Indeks Ketimpangan Gender (IKG) dengan Indeks Pembangunan Manusia (IPM) khusus perempuan maka akan terlihat bahwa Indeks Pembangunan Manusia (IPM) khusus perempuan yang tinggi menyebabkan Indeks Ketimpangan Gender (IKG) di provinsi tersebut semakin rendah (mendekati nol). Sebaliknya, jika Indeks Pembangunan Manusia (IPM) rendah maka angka Indeks Ketimpangan Gender (IKG) semakin tinggi, sehingga ketimpangan gender membesar. Pada tabel 1 terlihat hubungan antara Indeks Pembangunan Manusia (IPM) khusus perempuan dengan Indeks Ketimpangan Gender (IKG) negatif dan signifikan.

Tabel 1. Hasil analisis korelasi pearson antara Indeks Pembangunan Manusia

\section{Perempuan (IPM_P) dengan Indeks Ketimpangan Gender (IKG).}

\begin{tabular}{|l|l|l|}
\hline \multicolumn{2}{|c|}{ Korelasi Pearson } & IKG \\
\hline IPM_P & & $\mathrm{r}=-0,683$ \\
\cline { 3 - 3 } & & Sign $=0,000$ \\
\cline { 3 - 3 } & & $\mathrm{N}=34$ \\
\hline
\end{tabular}

Sumber : hasil olah data BPS, 2018

Tanda korelasi menunjukkan negatif, artinya jika terjadi kenaikan angka Indeks Pembangunan Manusia (IPM) maka angka Indeks Ketimpangan Gender (IKG) akan mengalami penurunan, demikian juga sebaliknya. Hal ini berarti untuk menurunkan ketimpangan gender maka segala variabel penyusun Indeks Pembangunan Manusia (IPM) perempuan baik pendidikan, kesehatan dan ekonomi harus ditingkatkan.

Kesimpulannya variabel Indeks Pembangunan Manusia (IPM) perempuan merupakan salah satu faktor yang menentukan kesetaraan gender semakin bagus di Indonesia. Indikator dalam Indeks Pembangunan Manusia (IPM) begitu berpengaruh karena wanita yang layak dan mampu sejajar dengan laki-laki adalah yang memiliki pendidikan tinggi, kesehatan yang bagus dan keadaan perekonomian yang baik.

\section{Indeks Pembangunan Gender}

Indeks Pembangunan Gender (IPG) Indonesia tahun 2018 mencapai angka 90,99. Artinya rasio Indeks Pembangunan Manusia (IPM) perempuan dibanding Indeks Pembangunan Manusia (IPM) laki-laki belum mencapi 100. Indikator penyusun Indeks Pembangunan Manusia (IPM) perempuan belum sekuat indikator Indeks Pembangunan Manusia (IPM) laki-laki. 
Dinamika Sosial Budaya, Vol 22, No. 2, Desember 2020, pp 234-247 p-ISSN: 1410-9859\& e-ISSN: 2580-8524 http://journals.usm.ac.id/index.php/jdsb

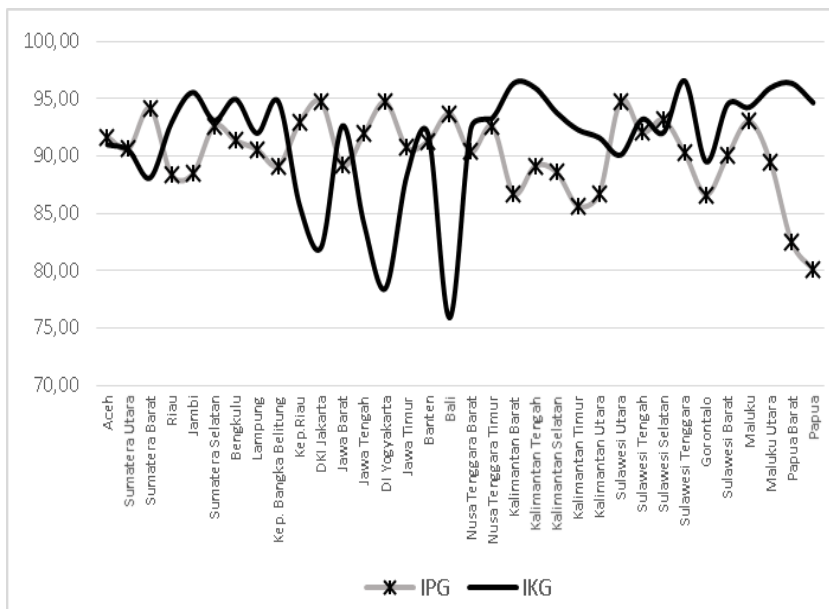

Gambar 4. Indeks Ketimpangan Gender (IKG) dan Indeks Pembangunan Gender (IPG) menurut Provinsi di Indonesia, 2018

Dari 34 provinsi di Indonesia, ada 15 provinsi yang Indeks Pembangunan Gender (IPG) berada di atas nasional. Di pulau sumatera ada lima provinsi yaitu Aceh, Kepulauan Riau, Sumatera Barat, Sumatera Selatan dan Bengkulu. Sementara di pulau Jawa ada 4 provinsi: DKI Jakarta, Banten, DI Yogyakarta dan Jawa Tengah. Di kawasan Indonesia timur ada Bali, NTT, Sulawesi Selatan, Sulawesi Barat, Sulawesi Utara dan Maluku.

Tingginya angka Indeks Pembangunan Gender (IPG) ternyata sangat berpengaruh terhadap Indeks Ketimpangan Gender (IKG). Hal tersebut ditandai dengan korelasi pearson sebesar 0,531 dengan arah negatif. Namun, apabila dibandingkan secara deskriptif per provinsi terlihat bahwa tidak semua provinsi mengikuti arah yang sama dengan korelasi pearson. Misalnya provinsi Gorontalo yang angka Indeks Ketimpangan Gender (IKG) rendah $(0,390)$ namun Indeks Pembangunan Gender (IPG) juga kecil $(86,63)$. Bahkan, provinsi Sulawesi Barat dan Maluku angka Indeks Ketimpangan Gender
(IKG) dan Indeks Pembangunan Gender (IPG) sama-sama tinggi.

Tabel 2. Hasil Analisis Korelasi Pearson antara Indeks Pembangunan Gender (IPG) dengan Indeks Ketimpangan Gender (IKG).

\begin{tabular}{|l|l|l|}
\hline \multicolumn{2}{|c|}{ Korelasi Pearson } & IKG \\
\hline IPG & & $\mathrm{r}=-0,531$ \\
\cline { 3 - 3 } & & Sign $=0,001$ \\
& & $\mathrm{~N}=34$ \\
\hline
\end{tabular}

Sumber : hasil olah data BPS, 2018

Selanjutnya dengan memperhatikan hasil analisis korelasi pearson pada tabel 2, terlihat bahwa hubungan antara Indeks Pembangunan Gender (IPG) dan Indeks Ketimpangan Gender (IKG) terbukti kuat dan signifikan dengan arah hubungan negatif. Hal ini berarti bahwa saat terjadi peningkatan Indeks Pembangunan Gender (IPG) maka akan terjadi perubahan kesetaraan yang lebih baik, berupa mengecilnya angka Indeks Ketimpangan Gender (IKG). Demikian juga sebaliknya, jika Indeks Ketimpangan Gender (IKG) melebar atau bertambah maka akan mengecilkan angka Indeks Pembangunan Gender (IPG).

\section{Persentase Perempuan Membaca Media Cetak dan Elektronik}

Angka persentase perempuan yang membaca media cetak maupun elektronik dalam Publikasi Statistik Kesejahteraan Rakyat 2018 yang diterbitkan oleh BPS mencantumkan bahwa hanya 16,94 persen perempuan Indonesia yang gemar membaca. Rendahnya budaya literasi perempuan Indonesia ditengarai oleh banyak faktor antara lain pendidikan, kesempatan, waktu 
Dinamika Sosial Budaya, Vol 22, No. 2, Desember 2020, pp 234-247 p-ISSN: 1410-9859\& e-ISSN: 2580-8524

http://journals.usm.ac.id/index.php/jdsb

dan tujuan perempuan membaca informasi. Seperti penelitian Ayu dkk yang menemukan literasi digital perempuan berhubungan dengan kemampuan meningkatkan kegiatan usaha mikro kecil dan menengah di Provinsi Yogyakarta (D. Ayu et al., n.d.).

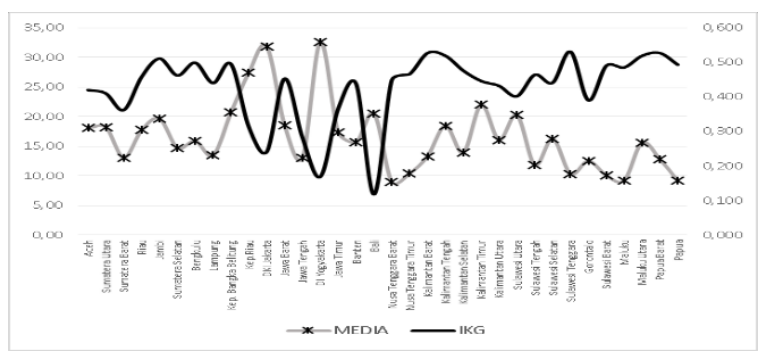

\section{Gambar 5. Indeks Ketimpangan Gender (IKG) dan Persentase Perempuan yang Membaca Media Cetak dan Elektronik menurut Provinsi di Indonesia, 2018}

Perempuan dan informasi harusnya tidak bisa dipisahkan, siapa yang mengusai media akan memenangkan pertarungan di era milenial. Dimana informasi menjadi bahan rujukan utama untuk mengembangkan bisnis, ekonomi dan perbaikan diri ke arah yang lebih baik. Secara nasional, persentase perempuan yang membaca media cetak dan elektronik masih rendah dibanding dengan laki-laki (21,52 persen). Apabila diamati maka provinsi DI Yogyakarta menduduki persentase budaya membaca media cetak dan elektronik tertinggi disusul DKI Jakarta. Sedangkan persentase terendah provinsi Nusa Tenggara Barat. Beberapa provinsi di kawasan Indonesia timur persentase perempuan membaca media cetak dan elektronik bahkan tidak sampai 12 persen.

\section{Tabel 3. Hasil Analisis Korelasi Pearson antara Persentase Perempuan Membaca Media Cetak dan Elektronik dengan Indeks Ketimpangan Gender (IKG).}

\begin{tabular}{|l|l|}
\hline Korelasi Pearson & IKG \\
\hline $\begin{array}{l}\text { Persentase } \\
\text { Perempuan } \\
\text { membaca media } \\
\text { cetak dan elektronik }\end{array}$ & $\mathrm{r}=-0,604$ \\
\cline { 2 - 2 } & $\mathrm{Sign}=0,000$ \\
\cline { 2 - 2 } & $\mathrm{N}=34$ \\
\hline
\end{tabular}

Sumber : BPS, 2018

Hasil analisis korelasi pearson antara persentase perempuan yang membaca media cetak dan eletronik dengan Indeks Ketimpangan Gender menunjukkan hubungan yang kuat dan signifikan. Arah hubungan negatif menunjukkan ketika semakin banyak persentase perempuan yang mengakses informasi lewat media cetak dan elektronik akan membuat Indeks Ketimpangan Gender (IKG) mengecil, yang berarti perempuan Indonesia semakin mampu untuk sejajar dengan pria. Demikian berlaku sebaliknya, ketika perempuan semakin malas, atau tidak memiliki waktu dan akses membaca akan membuat jurang ketimpangan semakin besar.

\section{Persentase Kepemilikan Hand Phone}

Hand Phone menjadi kebutuhan penting pada era milenial khusunya yang bebrbentuk smart phone. Persentase perempuan yang memiliki Hand Phone di Indonesia mencapai 57,19 persen, lebih rendah dari laki-laki yang mencapai 67,59 persen. Kepemilikan terhadap hand phone merupakan akses menuju beragamnya informasi dan teknologi yang dapat mendukung kemajuan perempuan. Walaupun diakui juga penguasaan teknologi cukup rentan bagi kaum hawa misalnya aksi pornografi dan selfie yang tidak bertanggung jawab (Purwanti dkk, 2016). 
Dinamika Sosial Budaya, Vol 22, No. 2, Desember 2020, pp 234-247 p-ISSN: 1410-9859\& e-ISSN: 2580-8524
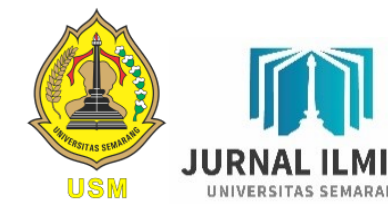

JURNAL ILMIAH

UNIVERSITAS SEMARANG

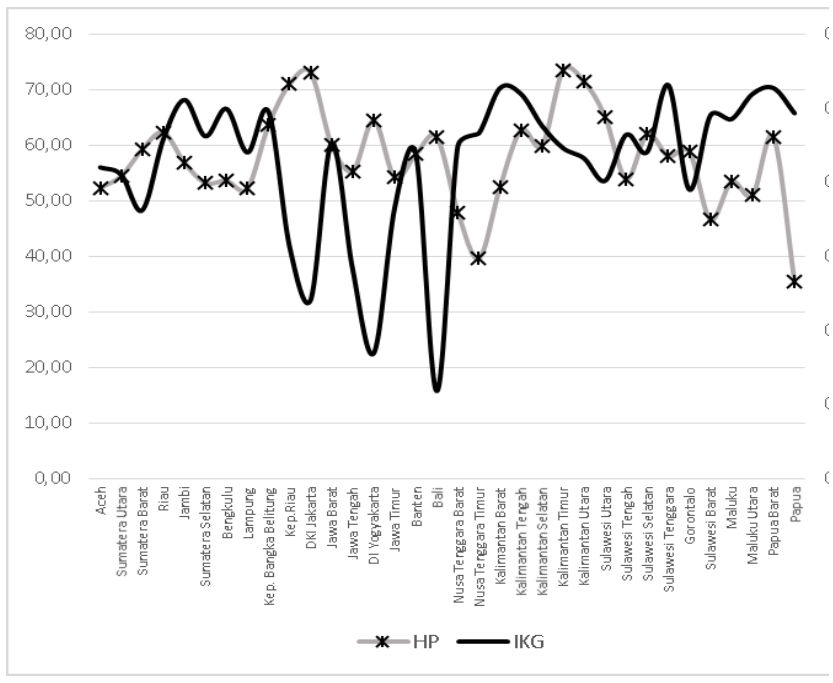

Gambar 6. Indeks Ketimpangan Gender (IKG) dan Persentase Perempuan yang Memiliki Hand Phone menurut Provinsi di Indonesia, 2018

DKI Jakarta menduduki peringkat pertama provinsi yang persentase perempuannya memiliki Hand Phone paling besar. Hidup di ibukota dengan tuntutan kebutuhan teknologi dan informasi yang tinggi. Akses yang cepat, mudah dan murah terhadap internet menjadikan warga Jakarta mempunyai kebutuhan lebih terhadap Hand Phone. Persentase perempuan yang memiliki Hand Phone terendah di papua. Hanya 35,42 persen perempuan di provinsi Indonesia bagian timur ini yang mempunyai Hand Phone.

Tabel 4. Hasil Analisis Korelasi Pearson antara Persentase Perempuan Memiliki Hand Phone dengan Indeks Ketimpangan Gender (IKG).

\section{Korelasi Pearson IKG}

$\begin{array}{lc}\begin{array}{l}\text { Persentase } \\ \begin{array}{l}\text { Perempuan } \\ \text { memiliki hand } \\ \text { phone }\end{array}\end{array} & \mathrm{r}=-0,364 \\ & \text { sign }=0,034 \\ \mathrm{n}= & 34\end{array}$

Sumber : BPS, 2018

Penghitungan korelasi pearson antara persentase perempuan yang memiliki hand phone dengan Indeks ketimpangan gender (IKG) menunjukkan angka 0,364 dengan arah negatif. Artinya kepemilikan hand phone terhadap kemampuan perempuan setara dengan laki-laki memiliki hubungan yang erat. Semakin besar persentase kepemilikan perempuan akan hand phone maka akan semakin menurun ketimpangan gendernya. Demikian pula sebaliknya, semakin rendah persentase perempuan memiliki hand phone maka akan semakin melebar ketimpangan gender suatu wilayah.

\section{Persentase Perempuan Menggunakan Komputer}

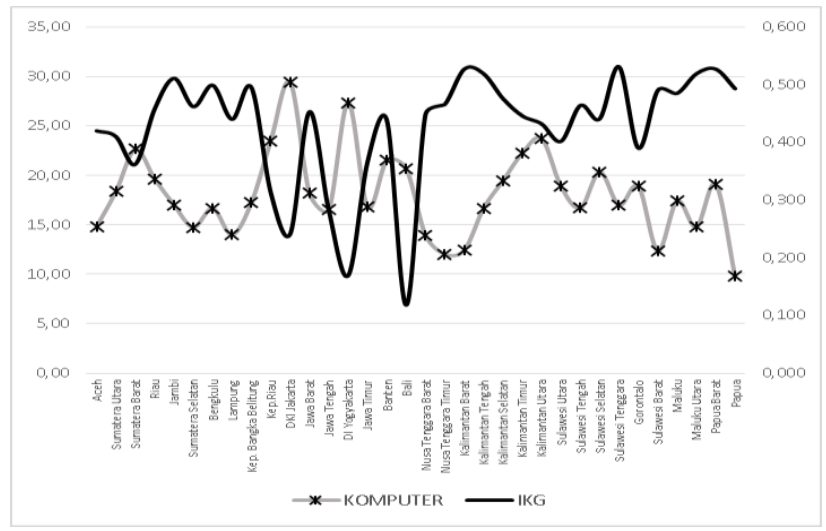

Gambar 7. Indeks Ketimpangan Gender (IKG) dan Persentase Perempuan yang Menggunakan Komputer menurut Provinsi di Indonesia, 2018 
Dinamika Sosial Budaya, Vol 22, No. 2, Desember 2020, pp 234-247 p-ISSN: 1410-9859\& e-ISSN: 2580-8524 http://journals.usm.ac.id/index.php/jdsb

Komputer yang dimaksud meliputi semua perangkat teknologi berupa personal computer/desktop, laptop dan tablet. Persentase perempuan yang menggunakan komputer di Indonesia mencapai 18,05 persen. Angka ini lebih rendah dari laki-laki dengan angka 20,15 persen. Dari 34 provinsi DKI Jakarta dan Papua masih menduduki posisi tertinggi dan terendah persentase perempuan yang menggunakan komputer.

Tabel 5. Hasil analisis korelasi pearson antara Persentase Perempuan

Menggunakan Komputer dengan Indeks Ketimpangan Gender (IKG).

\begin{tabular}{ll}
\hline \multicolumn{1}{c}{ Korelasi Pearson } & IKG \\
\hline $\begin{array}{l}\text { Persentase } \\
\text { Perempuan } \\
\text { menggunakan }\end{array}$ & $\mathrm{r}=-0,603$ \\
komputer & sign $=0,000$ \\
& $\mathrm{n}=34$
\end{tabular}

Sumber : BPS, 2018

Hubungan antara persentase perempuan yang menggunakan komputer dengan Indeks Ketimpangan Gender (IKG) kuat dan signifikan. Arahnya berlawanan ditandai dengan angka minus 0,603. Artinya penggunaan komputer oleh kaum hawa akan mempengaruhi kemampuannya untuk setara dengan kaum adam, ditandai dengan angka korelasi yang besar. Semakin tinggi persentase perempuan menggunakan komputer maka kesetaraan akan terjadi karena nilai Indeks Ketimpangan Gender (IKG) semakin kecil. Berlaku juga hal sebaliknya, semakin rendah persentase perempuan menggunakan komputer akan menambah lebar ketimpangan gender.

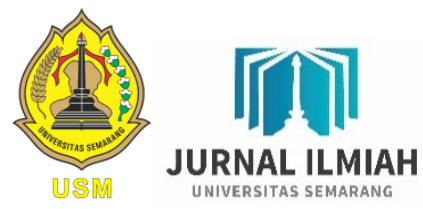

Namun, apabila dilihat lebih dalam kasus per provinsi maka akan didapati Provinsi Banten dan Papua Barat mengalami hal berbeda. Di Banten dan Papua Barat semakin tinggi persentase perempuan menggunakan komputer justru tingkat ketimpangan semakin melebar.

\section{Persentase Perempuan Mengakses Internet}

Internet dalam konsep publikasi statistik kesejahteraan rakyat mencakup semua jenis internet baik facebook, twitter, BBM maupun whatsapp. Provinsi dengan persentase perempuan yang mengakses internet peringkat tiga besar yaitu DKI Jakarta, DI Yogyakarta dan Kepulauan Riau. Sementara itu, apabila diamati hubungan antara persentase perempuan yang mengakses internet dengan Indeks Ketimpangan Gender (IKG) maka akan diperoleh korelasi yang kuat dan signifikan. Ditandai dengan angka korelasi pearson yang besar $(0,604)$ dengan arah negatif.

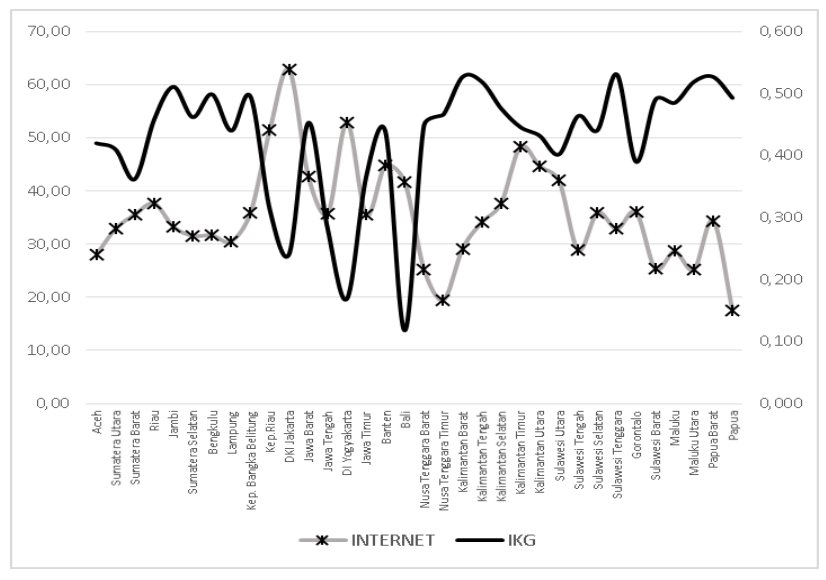

Gambar 8. Indeks Ketimpangan Gender (IKG) dan Persentase Perempuan yang Mengakses Internet menurut Provinsi di Indonesia, 2018 
Dinamika Sosial Budaya, Vol 22, No. 2, Desember 2020, pp 234-247 p-ISSN: 1410-9859\& e-ISSN: 2580-8524

http://journals.usm.ac.id/index.php/jdsb

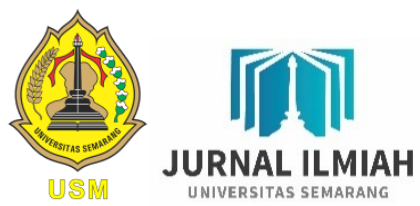

Pentingnya internet bagi perempuan untuk menjadi modal bagi pengembangan diri dan mengasah kemampuannya agar sejajar dengan laki-laki terpotret dalam korelasi pearson ini. Semakin besar persentase perempuan mengakses internet maka akan semakin kecil ketimpangan dan berlaku sebaliknya. Tidak bisa dipungkiri bahwa internet menjadi magnet bagi segala informasi dan teknologi digital di era milenial.

Tabel 6. Hasil Analisis Korelasi Pearson antara Persentase Perempuan Mengakses Internet dengan Indeks Ketimpangan Gender (IKG).

\begin{tabular}{lcc}
\hline \multicolumn{1}{c}{ Korelasi Pearson } & IKG \\
\hline $\begin{array}{l}\text { Persentase } \\
\text { Perempuan } \\
\text { Menggunakan }\end{array}$ & $\mathrm{r}=-0,604$ \\
Komputer & sign $=0,000$ \\
& $\mathrm{n}=34$ \\
\hline
\end{tabular}

Sumber : BPS, 2018

\section{SIMPULAN}

Berdasarkan hasil pembahasan di atas maka dapat disimpulkan bahwa Indeks Ketimpangan Gender (IKG) di Indonesia menunjukkan perubahan ke arah yang lebih baik. Hal itu ditandai angka Ketimpangan Gender (IKG) yang semakin kecil dari tahun ke tahun. Terdapat Hubungan yang kuat antara Indeks Pembangunan Manusia (IPM), Indeks Pembangunan Gender (IPG) dengan Indeks Ketimpangan Gender (IKG) ditandai dengan korelasi pearson yang tinggi.

\section{DAFTAR PUSTAKA}

Ahang, M. (2014). The Impact of Gender Inequality on Economic Growth in Developed Countries. Advances in Environmental Biology, 8(17), 508513.

Terdapat korelasi yang kuat, signifikan dan negatif pada empat variabel sosial teknologi informasi. Variabel tersebut antara lain persentase perempuan membaca media cetak dan elektronik, persentase perempuan memiliki hand phone, persentase perempuan menggunakan komputer dan persentase perempuan mengakses internet. Hasil penelitian ini membuktikan bahwa variabel sosial teknologi dan informasi berpengaruh terhadap kesetaraan gender. Terbukti dengan korelasi yang kuat dan signifikan antara empat variabel sosial teknologi informasi yang diteliti dengan Indeks Ketimpangan Gender (IKG).

Alfana, M. A. F., Fauzan A, D., Laksmiasri, W., \& Rahmaningtias, A. (2015). Dinamika Pembangunan Manusia Berbasis Gender Di Indonesia. Seminar Nasional Geografi Ums 2015, 1-21.

Ayu, D., Widyastuti, R., Nuswantoro, R., \& Purnomo, A. (n.d.). LITERASI DIGITAL PADA PEREMPUAN PELAKU USAHA. 1-15.

Ayu, R. K. (2017). Perempuan Pebisnis Startup di Indonesia dalam Perspektif Cybertopia. Jurnal Studi Komunikasi (Indonesian Journal of Communications Studies), 1(2), 116- 
Dinamika Sosial Budaya, Vol 22, No. 2, Desember 2020, pp 234-247 p-ISSN: 1410-9859\& e-ISSN: 2580-8524

http://journals.usm.ac.id/index.php/jdsb

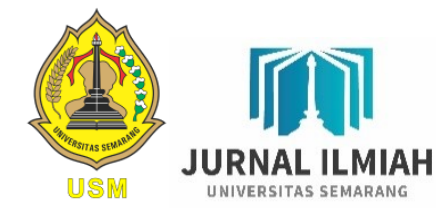

130.

https://doi.org/10.25139/jsk.v1i2.167

Gender Gap Report 2020: Insight Report.

https://doi.org/10.1002/97811190856

Badan Pusat Statistik. (2015). Pembangunan 21.wbefs 350

Manusia Berbasis Gender Provinsi Jawa Timur 2015. 59.

Badan Pusat Statistik. (2019). Penghitungan Indeks Ketimpangan Gender 2018 (Kajian Lanjutan 2).

Elvina. (2013). Pendapatan Perkapita Di Sumatera Utara. QE Journal, 02(02), 25-34. https://qejournal.github.io/publications/QEJVol-02-No-02-Article-03-Elvina.pdf

Jais, A. (n.d.). GENDER ANALISIS DAN PEMETAAN INDEK. 5.

Kabupaten, D. I., \& Tahun, B. (2017). Potret Pembangunan Manusia Berbasis Gender. 6, 1627-1635.

Lubis, E. E. (2014). Potret media sosial dan perempuan. Paralella, Volume I N, 97-106.

Najih, M. A. (2017). Gender Dan Kemajuan Terknologi. 12(2), 18-26.

Rita Diana. (2018). Analisis Ketimpangan Gender Di Provinsi Sumatera Barat ( Gender Inequality Analysis in West Sumatera Province ). 13(1), 55-66.

United Nations Development Programme. (2019). Human Development Report 2019: Beyond income, beyond averages , beyond today. http:/hdr.undp.org/sites/default/files/ hdr2019.pdf

World Economic Forum. (2019). Global 